\title{
25 Research Square \\ Study on Stability of Exit Slope of Chenjiapo Tunnel Under Condition of Long-term Rainfall
}

Tian-shun Hou ( $\nabla$ houtianshunyx@sina.com )

Northwest A\&F University https://orcid.org/0000-0001-9236-6656

Xiang Duan

Northwest A\&F University: Northwest Agriculture and Forestry University

Hao-yu Liu

Northwest A\&F University: Northwest Agriculture and Forestry University

\section{Research Article}

Keywords: Chenjiapo tunnel, slope stability, long term rainfall, finite element method, safety factor, plastic zone

Posted Date: June 21st, 2021

DOI: https://doi.org/10.21203/rs.3.rs-176316/v1

License: (c) (1) This work is licensed under a Creative Commons Attribution 4.0 International License. Read Full License

Version of Record: A version of this preprint was published at Environmental Earth Sciences on August 21st, 2021. See the published version at https://doi.org/10.1007/s12665-021-09895-x. 


\section{Abstract}

The exit slope of Chenjiapo Tunnel is located directly above the exit of Chenjiapo Tunnel on Enshi to Laifeng expressway. During the excavation of the exit of the right line of the tunnel, the left side of the front edge of the slope slips. Under the joint action of excavation and rainfall, a large landslide of $6.27 \times 104 \mathrm{~m} 3$ and a huge unstable slope of $8.69 \times 105 \mathrm{~m} 3$ are formed. The landslide body and unstable slope body not only cause the tunnel to be shut down, but also directly threaten the operation safety of the later expressway. Therefore, in order to study the stability change process of the exit slope of Chenjiapo tunnel under the condition of long-term rainfall, the finite element calculation of the slope is carried out by GeoStudio software. The results show that under the condition of long-term continuous rainfall, the safety factor of the slope decreases with the increased rainfall time, but the reduction rate gradually slows down, and finally tends to be stable. The safety factor of the slope is reduced from 1.187 in the natural state to 1.015 , which indicates that the slope is still in a stable state under the condition of long-term continuous rainfall, but the safety reserve is not high, and it is easy to lose stability and damage due to the influence of external adverse factors. As the rainfall continues, the seepage line inside the slope is rising, and the saturated area of the soil at the toe of the slope is increasing. Until the slope begins to drain outwards, the seepage field inside the slope is basically stable. The maximum horizontal displacement of the slope increases with the increased rainfall time, but the increase rate gradually slows down until it tends to be stable. The maximum horizontal displacement of the slope occurred in the middle surface of the slope at the beginning of the rainfall, and gradually transferred to the toe of the slope within 7 days of the rainfall and continued until the end of the rainfall. At the end of the rainfall, the maximum horizontal displacement of the toe of the slope is $0.128 \mathrm{~m}$, and the toe of the slope will be damaged first. At the beginning of the rainfall, the plastic zone of the slope is only scattered at the slope surface and the slope toe. And then as the rainfall continues, the distribution range of the plastic zone in the slope surface, the slope toe and the slide zone gradually widen, and the slope stability gradually decreases. The maximum horizontal displacement and plastic zone of the slope are concentrated at the toe of the slope, the slope presents obvious traction failure characteristics. According to the results of field survey, there are small-scale gravel soil collapses and shear outlets at the front edge of the slope, and the survey results are consistent with the simulation results. It is suggested to set up perfect drainage engineering in the middle and back of the slope, and set anti slide piles and drainage holes at the toe of the slope to reinforce the slope.

\section{Full Text}

This preprint is available for download as a PDF. 